Section Editor Mitchell S.V. Elkind, MD, MS
Address correspondence and reprint requests to Dr. B. Nazarov, Department of Neurology, Pierre ZobdaQuitman Hospital, Route de Jambette 25, Fort-de-France, Martinique

nazaroffba@mail.ru

\section{Teaching NeuroImages: \\ Bilateral anterior thalami and \\ fornix macrohemorrhage in \\ Wernicke-Korsakoff syndrome}
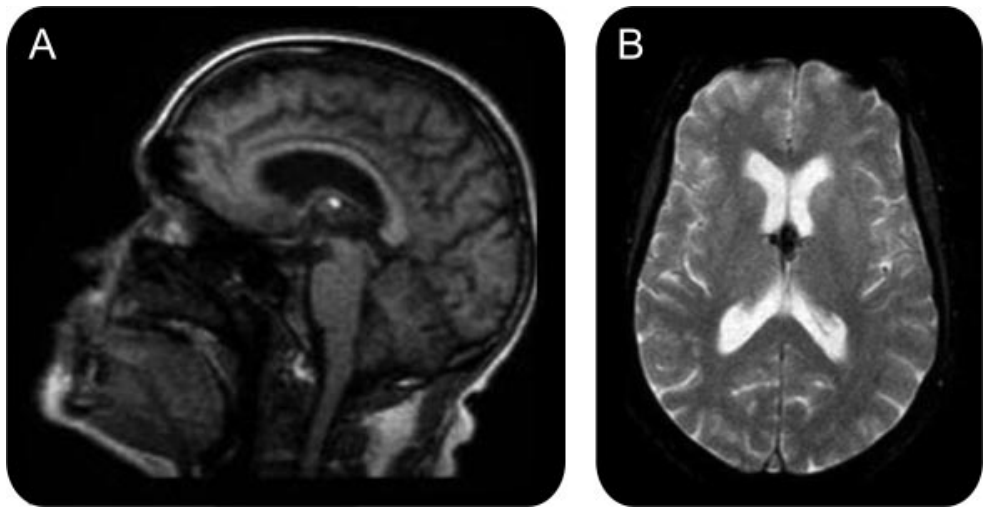

Sagittal T1-weighted MRI (A) shows hemorrhage involving the anterior thalamus just beneath the fornix. Axial T2*-weighted MRI (B) shows bilateral fornix hemorrhage with asymmetrical bithalamic involvement.

A 55-year-old man with alcoholism required sigmoid resection for complicated diverticulitis. A few weeks after starting parenteral nutrition, he developed multidirectional gaze nystagmus, gait ataxia, and confusion, leading to the diagnosis of Wernicke encephalopathy. Thiamine treatment was started and his symptoms improved, helping to confirm the diagnosis. However, the patient developed memory loss consistent with Korsakoff syndrome due to hemorrhage involving the fornix and the bilateral anterior thalami (figure). More typical fluid-attenuated inversion recovery lesions (mamillary bodies, tectal plate, and periaqueductal area), which may be reversible, ${ }^{1}$ were not seen. Macroscopic hemorrhage is rarely observed in Wernicke-Korsakoff syndrome ${ }^{2,3}$ and is associated with poor prognosis. ${ }^{3}$

\section{AUTHOR CONTRIBUTIONS}

Dr. Nazarov: drafting/revising the manuscript, analysis or interpretation of data, contribution of vital reagents/tools/patients, acquisition of data, study supervision. Dr. Jeannin: drafting/revising the manuscript, study concept or design, contribution of vital reagents/tools/patients, acquisition of data, study supervision. Dr. Mejdoubi: drafting/revising the manuscript, analysis or interpretation of data. Dr. Signate: drafting/revising the manuscript. Dr. Smadja: drafting/revising the manuscript, analysis or interpretation of data.

\section{REFERENCES}

1. Antunez E, Estruch R, Cardenal C, et al. Usefulness of CT and MR imaging in the diagnosis of acute Wernicke's encephalopathy. AJR Am J Roentgenol 1998;171: 1131-1137.

2. Helbok R, Beer R, Engelhardt K, et al. Intracerebral haemorrhage in a malnourished patient, related to Wernicke's encephalopathy. Eur J Neurol 2008;15:e99-e100.

3. Pfister HW, von Rosen F. Severe intraventricular haemorrhage shown by computed tomography as an unusual manifestation of Wernicke's encephalopathy. J Neurol Neurosurg Psychiatry 1995;59:555-565. 


\section{Neurology}

\section{Teaching NeuroImages: Bilateral anterior thalami and fornix macrohemorrhage in Wernicke-Korsakoff syndrome}

B. Nazarov, S. Jeannin, M. Mejdoubi, et al.

Neurology 2011;77; e129

DOI 10.1212/WNL.0b013e31823a0ca5

This information is current as of November 28, 2011

Updated Information \& Services

References

Subspecialty Collections

Permissions \& Licensing

Reprints including high resolution figures, can be found at: http://n.neurology.org/content/77/22/e129.full

This article cites 3 articles, 1 of which you can access for free at: http://n.neurology.org/content/77/22/e129.full\#ref-list-1

This article, along with others on similar topics, appears in the following collection(s):

All Clinical Neurology

http://n.neurology.org/cgi/collection/all_clinical_neurology Intracerebral hemorrhage

http://n.neurology.org/cgi/collection/intracerebral_hemorrhage MRI

http://n.neurology.org/cgi/collection/mri

Nutritional

http://n.neurology.org/cgi/collection/nutritional

Information about reproducing this article in parts (figures,tables) or in its entirety can be found online at:

http://www.neurology.org/about/about_the_journal\#permissions

Information about ordering reprints can be found online:

http://n.neurology.org/subscribers/advertise

Neurology ${ }^{\circledR}$ is the official journal of the American Academy of Neurology. Published continuously since 1951, it is now a weekly with 48 issues per year. Copyright Copyright $@ 2011$ by AAN Enterprises, Inc.. All rights reserved. Print ISSN: 0028-3878. Online ISSN: 1526-632X.

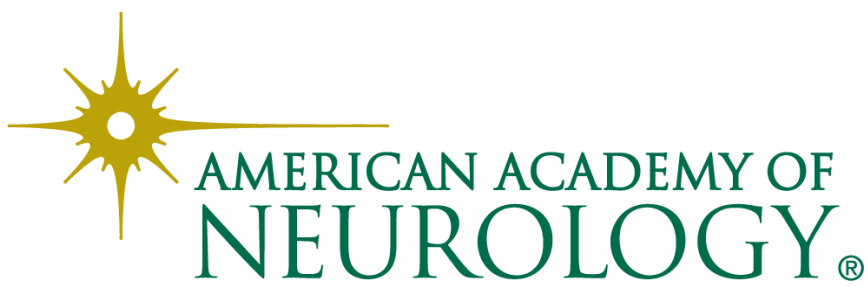

